\title{
Evaluation of The Healing Effects of Aqueous Extracts of Musa Paradisiaca (Unripe Plantain) And Brassica Oleracea (Cabbage) on Peptic Ulcer.
}

\author{
Enye J.C. ${ }^{1}$ Chineke H. N. ${ }^{2}$, Onubeze D.P.M. ${ }^{3}$, Nweke I. ${ }^{4}$ \\ ${ }^{1}$ Department of Pharmacology, Madonna University Elele River State Nigeria. \\ ${ }^{2}$ Department of Family Medicine Imo State University Teaching Hospital Orlu South Eastern Nigeria. \\ ${ }^{3}$ Department of Community Medicine \& Primary care, Anambra State University Teaching Hospital, Awka, \\ Nigeria \\ ${ }^{4}$ Department of Pharmacology, Abia State University Teaching Hospital, Aba, Nigeria
}

\begin{abstract}
:
Background: Peptic ulcer results from an imbalance between ulcer promoting factors (gastric acid, pepsin secretion) and ulcer preventing factors (gastric mucosa, prostaglandins). Unripe plantain and cabbage when used individually were effective in the treatment of peptic ulcer in folkloric medium. This hereby paved way for this research that involved the co-administration of aqueous extracts of Musa paradisiaca (plantain) and Brassica oleracea (cabbage) in the treatment of peptic ulcer.

Objectives: To evaluate the healing effect of the aqueous extracts of Musa paradisiaca (plantain) and Brassica oleracen (cabbage) on peptic ulcer in rats, and the possible effect of these materials as prophylaxis against peptic ulcer. This could pave way for the production of anti-peptic ulcer drugs for use in clinical medicine.

Methodology: A total of 45 rats of both sexes weighing 200-250g were used for this study. In the prophylactic study, 15 adult albino wistar rats were used. The animals were grouped into 5 groups of 3 animals each and were starved for 24 hrs before the experiment. Group 1 received $0.3 \mathrm{ml}$ of distilled water, group 2 received $100 \mathrm{mg} / \mathrm{kg}$ of cimetidine, group 3 received 100mg/kg of Brassica oleracae extract, group 4 received 100mg/ $\mathrm{kg}$ of Musa parasidiaca extract and group 5 received a combination of Musa paradistaca and Brassica oleracea extracts at the dose of $50 \mathrm{mg} / \mathrm{kg}+50 \mathrm{mg} / \mathrm{kg}$.

I hr post treatment, peptic ulcer was induced in all the animals by a single oral administration of $30 \mathrm{mg} / \mathrm{kg}$ of Indomethacin. $8 \mathrm{hrs}$ after ulcer induction, each animal was sacrificed and the number of lesions in the stomach was counted. In the curative study, a total number of 30 rats were used. They were grouped into 5 groups of 6 animals each. The animals were denied access to food and water for $24 \mathrm{hrs}$. Ulcer was induced in all the groups by single oral administration of $30 \mathrm{mg} / \mathrm{kg}$ indomethacin. $8 \mathrm{hrs}$ post ulcer induction, 2 animals from each group were sacrificed and the number of ulcer counted. The remaining animals in each group received treatment as follows: group 1 received $0.3 \mathrm{ml}$ of distilled water, group 2 received 100mg/kg of cimetidine, group 3 received 100mg/kg of Brassica oleracea extract, group 4 received 100mg/kg of Musa paradisiaca extract and group 5 received $50 \mathrm{mg} / \mathrm{kg}$ combination of Musa paradisiaca and Brassica extract. They received the treatment for three days, then another 2 animals from each group were sacrificed and their number of ulcers counted.

The remaining animals contained to receive treatment for another three days before their ulcer index were determined.

The LD 50 test was carried out using the Lorke's method. The phytochemical analysis was conducted using the trease and Evans method.

Results: It showed that the co-administration of aqueous extract of Musa paradisiaca and Brassica oleracea possessed peptic ulcer healing activity, and had more of prophylactic effect than curatve effect.

It also showed that the separate dose of Musa paradisiaca extract and Brassica oleracea possesses more curative anti ulcer action when used individually than when co-administered.

Conclusion: The extracts of Musa paradisiaca and Brassica oleracea has peptic ulcer healing activity. This could find some relevance in the treatment of peptic ulcer disease. Clinicians and pharmacologists will find this study highly relevant with a view to actually formulating a medicament from the extracts for use in the treatment of peptic ulcer disease in man.
\end{abstract}

Key Words: Musa paradisiaca, Brassica oleracea, peptic ulcer.

\section{Introduction}

Musa paradisiaca (plantain fruit) is an important food in the humid tropical zone of Africa ${ }^{(1)}$

It is undoubtedly one of the oldest cultivated crops in West Africa. It is called Ojoko by the Igbos in Nigeria. It has about 40 species and it is a perennial carbohydrate food crop with gestation period of 14 to 20 
months. The plant has a dark green foliage leaves with distant paralled ribs along their length. Its major harvest occurs between September and March $^{(1)}$. It contains flavonovids which contribute to its use in the treatment of certain diseases ${ }^{(2)}$

Cabbage which is known as Brassica oleracea is a popular leafy vegetable. It is a herbaceous, biennial, dicotyledonous flowering plant.

Traditional healing system plays an important role in health care delivery of many nations, and about $70 \%$ of the worlds population has incorporated traditional medicine into their primary modality of healthcare medicinal herbs constitutes the base of traditional medicine worldwide ${ }^{(4)}$.

Research in medicinal plants has provided scientific basis for the use of whole plants or parts of it for treatment of some ailments ${ }^{(5)}$. Unripe plantain (Musa paradisiaca) is a good source of carbohydrates and also rich in potassium and provitamin A. (carotene) ${ }^{(6)}$. Besides its folkloric use in the treatment of peptic ulcer, Musa paradisiaca is also effective in the treatment of disorders like diarrhea and vomiting ${ }^{(7)}$.

Its main constituents are carbohydrates, alkaloids, glycosides, saponins, proteins and steroids ${ }^{(8) .}$ Plantain leaf can be considered as a "green bandage" as it has healing properties useful in the treatment of skin infection, wounds and rashes ${ }^{(9)}$. Musa paradisiaca leaf poultices are also used in the treatment of toothaches and gum abscesses ${ }^{(10)}$. Unripe plantain when used as an expectorant, helps to expel phlegm from the respiratory tract (11). It also has astringent properties which is used in folkloric medicine for the treatment of urinary tract infections and haemorrloids ${ }^{(12)}$.

\section{Correspondence:}

ONUBEZE D.P.M. Department of Community Medicine \& Primary Care, Anambra State University Teaching Hospital, Awka, Nigeria.

08039326677. onubezedave@gmail.com

On the other hand, cabbage (Brassica Oleracea) is extremely nutritious whether taken as meal or as medicine, and is an excellent source of vitamin $\mathrm{C}$ and glutamine ${ }^{(13),(14)}$.

Fresh Brassica oleracea juice besides its antipeptic ulcer property, is also useful in the treatment of cancer, and gastrointestinal diseases ${ }^{(15),(16)}$.

\section{Materials And Methods}

\section{Drugs and Other Materials Used}

Cimelidine, Indomethacin, distilled water, electronic weighing balance, syringes, grinder, mortar and pestle, mechanical weighing balance, dissecting set, filter paper, rotary evaporator, oven, mechanical shaker, powdered samples of Musa paradisiacal and Brassica Oleracea

\section{Collection And Identification of Plant Material}

The unripe plantain and cabbage used for this work were purchased from a local market at Owerri Imo State and sent for identification at the pharmacology department of Madonna University Elele.

\section{Preparation Of Aqueous Extract}

The unripe plantain and cabbage fruits were peeled, sliced into tiny pieces, sundried and milled to powder afterwards using an industrial grinding machine.

A aqueous extraction was done with cold distilled water by soaking 300g of Musa paradisiaca powder and $200 \mathrm{~g}$ of Brassica Oleracea powder separately in $1000 \mathrm{mls}$ of distilled water each, and placed on a mechanical shaker for 48 hrs. Their mixtures were then filtered into a glass bottle using a clean white handkerchief. They were further filtered with filter paper and concentrated using a rotary evaporator.

Afterwards they were oven dried with hot air oven at $50^{\circ} \mathrm{C}$. Their concentrates were then assessed for activity against indomethacin induced ulceration by the prophylactic and curative procedures.

\section{Phytochemical Test}

It was carried out on the extracts using the Trease and Evans procedure. It showed the presence of some active biological agents that could be responsible for their various curative actions.

\section{Experimental Animals}

Adult wistar rats (200-250g) and mice (67-90g) of either sex were used for this study. The animals were sourced from the animal house of the department of Zoology, University of Nigeria Nsukka. They were kept in the department of pharmacology of Madonna University and they had free access to food and clean water. Permission was obtained from the ethical committee on animal use of Madonna University Elele before the research was conducted. 


\section{Acute Toxicity Test}

Dietrich Lorke's method was used. ${ }^{(17)}$ It employed the use of 13 mice in two stages. The first state was a preliminary trial using 3 different doses of the extracts. The animals were grouped into 3 groups of 3 animals each. Group1 received a single oral dose of the extract at $10 \mathrm{mg} / \mathrm{kg}$, Group 2, received $100 \mathrm{mg} / \mathrm{kg}$, while group 3 received $1000 \mathrm{mg} / \mathrm{kg}$. The animals were constantly monitored for the first 2 hours post administration and the intermittently for the next $6 \mathrm{hrs}$ and then $24 \mathrm{hrs}$.

The number of deaths were noted. From the result of the first stage, the second stage was carried out. In this stage, the animals were grouped into 4 , each having one animal. The first group received $1500 \mathrm{mg} / \mathrm{kg}$ of the extract, group 2 received $2500 \mathrm{mg} / \mathrm{kg}$, group 3 received $3500 \mathrm{mg} / \mathrm{kg}$ while group 4 received $5000 \mathrm{mg} / \mathrm{kg}$.

The animals were monitored for a period of $24 \mathrm{hrs}$ and the number of deaths also noted. This test was carried out on both Musa paradisiaca and Brassica Oleracea extracts.

\section{Anti Ulcer Test \\ Prophylactic Test}

15 adults wistar rats were used for this test. The animals were grouped into 5 groups of 3 animals each and they were starved for $24 \mathrm{hrs}$ to prior to the experiment. Group 1 received $0.3 \mathrm{ml}$ of distilled water, group 2 received $100 \mathrm{mg} / \mathrm{kg}$ of cimetidine, group 3 received Brassica Oleracea extract at the dose of $100 \mathrm{mg} / \mathrm{kg}$, group 4 received $100 \mathrm{mg} / \mathrm{kg}$ of Musa paradisiacal extract, while group 5 received a combination of Musa paradisiaca and Brassica Oleracea extract at the doses of $50 \mathrm{mg} / \mathrm{kg}+50 \mathrm{mg} / \mathrm{kg}$. hour after treatment, ulcer was induced in each of the animals by a single oral administration of $30 \mathrm{mg} / \mathrm{kg}$ of indomethacin, $8 \mathrm{hrs}$ after the ulcer induction, each animal was sacrificed and their stomach dissected out. It was ligated along the greater curvature. Then it was held with the finger and a stream of water ran through it to wash it, then the number of ulcers were counted.

\section{Curative Test}

In this test, a total of 30 rats were used. They were grouped into 5 groups of 6 animals each. The animals were starved of food an water for $24 \mathrm{hrs}$. Then ulcer was induced by a single oral dose of $30 \mathrm{mg} / \mathrm{kg}$ of indomethacin, $8 \mathrm{hrs}$ post ulcer induction, 2 animals from each group were sacrificed and the number of ulcers counted using the procedure as was described in the prophylactic test.

The remaining animals in each group received treatment as follows:

Group 1 received $0.3 \mathrm{ml}$ of distilled water, group 2 received $100 \mathrm{mg} / \mathrm{kg}$ cimetidine, group 3 received $100 \mathrm{mg} / \mathrm{kg}$ of Brassica Oleracea extract, group 4 received $100 \mathrm{mg} / \mathrm{kg}$ of Musa paradisiaca extract, while group 5 received a combination of both extracts at a dose of $50 \mathrm{mg} / \mathrm{kg}+50 \mathrm{mg} / \mathrm{kg}$. They received the treatment for 3days, then another 2 animals from each group were sacrificed and their number of ulcer lesions counted. The remaining animals continued to receive treatment for another 3 days before their ulcer index were determined.

\section{Statistical Analysis}

Results were expressed as mean + standard error of mean (SEM). The significance of difference between means of control and treated groups were determined by one way analysis of variance (ANOVA). Results were regarded as significant with $\mathrm{P}<0.05$ or not significant with $\mathrm{P}>0.05$.

\section{Results And Tables}

Table 1: Phytochemical analysis result of M. Paradisiaca

\begin{tabular}{|l|c|}
\hline Phytochemical constituent & Degree present \\
\hline Carbohydrates & +++ \\
\hline Reducing sugar & + \\
\hline Alkaloids & +++ \\
\hline Glycoside & +++ \\
\hline Saponin & + \\
\hline Protein & ++ \\
\hline Steroid & + \\
\hline
\end{tabular}

Key:

$+++=$ Present in large amount

$++=$ Moderately present

$+\quad=$ Present in trace amount 
Table 2: Phytochemical analysis results of Brassica Oleracea.

Key:

\begin{tabular}{|l|c|}
\hline Phytochemical constituent & Degree present \\
\hline Carbonhydrates & +++ \\
\hline Alkaloid & +++ \\
\hline Glycoside & +++ \\
\hline Reducing sugar & ++ \\
\hline Protein & ++ \\
\hline Steroids & ++ \\
\hline Saponin & + \\
\hline
\end{tabular}

$+++=$ Present in large amounts

$++\quad=$ Moderately present

$+\quad=$ Present in trace amount

Table 3: Acute Toxicity Test Result of M. paradisiaca

\begin{tabular}{|c|c|c|c|}
\hline Stage & Dose $\mathbf{~ m g / k g}$ & $\begin{array}{c}\text { Number of } \\
\text { deaths }\end{array}$ & $\begin{array}{c}\text { Number of } \\
\text { survivals }\end{array}$ \\
\hline 1 & 10 & $0 / 3$ & $3 / 3$ \\
\hline & 100 & $0 / 3$ & $3 / 3$ \\
\hline & 100 & $0 / 3$ & $3 / 3$ \\
\hline 2 & 1500 & $0 / 3$ & $1 / 1$ \\
\hline & 2500 & $0 / 1$ & $1 / 1$ \\
\hline & 3500 & $0 / 1$ & $1 / 1$ \\
\hline & 5000 & $0 / 1$ & $1 / 1$ \\
\hline
\end{tabular}

$\mathrm{LD} 50>5000 \mathrm{mg} / \mathrm{kg}$

Table 4: Acute Toxicity Test Result of B. Oleracea

\begin{tabular}{|c|c|c|c|}
\hline Stage & Dose $\mathbf{m g} / \mathbf{k g}$ & $\begin{array}{c}\text { Number of } \\
\text { deaths }\end{array}$ & $\begin{array}{c}\text { Number of } \\
\text { survivals }\end{array}$ \\
\hline 1 & 10 & $0 / 3$ & $3 / 3$ \\
\hline & 100 & $0 / 3$ & $3 / 3$ \\
\hline & 1000 & $0 / 3$ & $3 / 3$ \\
\hline 2 & 1500 & $0 / 1$ & $1 / 1$ \\
\hline & 2500 & $0 / 1$ & $1 / 1$ \\
\hline & 3500 & $0 / 1$ & $1 / 1$ \\
\hline & 5000 & $0 / 1$ & $1 / 1$ \\
\hline
\end{tabular}

LD50 > 5000mg/kg.

Table 5: Result of Prophylactic treatment with Cimetidine and extracts. Mean + SEM

\begin{tabular}{|c|c|c|c|c|c|c|}
\hline Group & Agent and dose & $\begin{array}{l}\text { No of } \\
\text { animals } \\
\text { used }\end{array}$ & $\begin{array}{l}\text { No } \\
\text { animals } \\
\text { having } \\
\text { ulcer }\end{array}$ & $\begin{array}{l}\text { Percenta } \\
\text { ge } \\
\text { having } \\
\text { ulcers \% }\end{array}$ & Ulcer index & $\begin{array}{l}\text { Percentage } \\
\text { ulcer } \\
\text { inhibition \% }\end{array}$ \\
\hline 1 & $\begin{array}{l}\text { Distilled water } \\
(0.3 \mathrm{ml})\end{array}$ & 3 & 3 & 100 & $\begin{array}{l}2.9 \\
\pm \\
1.10\end{array}$ & 0 \\
\hline 2 & $\begin{array}{l}\text { Cimetidine } \\
(100 \mathrm{mg} / \mathrm{kg})\end{array}$ & 3 & 1 & 33.33 & $\begin{array}{l}* 0.4 \\
\pm \\
0.11\end{array}$ & 86.21 \\
\hline 3 & $\begin{array}{l}\text { Brassica } \\
\text { Oleracea extract } \\
(100 \mathrm{mg} / \mathrm{kg})\end{array}$ & 3 & 2 & 66.66 & $\begin{array}{l}* 0.25 \\
+\quad \\
0.05\end{array}$ & 91.38 \\
\hline 4 & $\begin{array}{l}\text { Musa paradisiaca } \\
\text { extract } \\
(100 \mathrm{mg} / \mathrm{kg})\end{array}$ & 3 & 2 & 66.66 & $\begin{array}{l}* 0.6 \\
+ \pm \\
0.20\end{array}$ & 79.32 \\
\hline 5 & $\begin{array}{l}\text { M. parasid + B. } \\
\text { Oleracea extracts } \\
(50 \mathrm{mg} / \mathrm{kg}+50 \\
\mathrm{mg} / \mathrm{kg})\end{array}$ & 3 & 3 & 100 & $\begin{array}{l}* 1.18 \\
+ \\
0.4\end{array}$ & 59.32 \\
\hline
\end{tabular}

Keys: $*$ Significant $(\mathrm{P}<0.05)$ 
Table 6: Result of curative treatment with cimetidine and extracts.

\begin{tabular}{|c|c|c|c|c|c|}
\hline \multicolumn{6}{|c|}{ Mean + SEM } \\
\hline Group & Dose and agent & $\begin{array}{l}\text { Day zero } \\
\text { ulcer } \\
\text { index }\end{array}$ & $\begin{array}{ll}\text { Day } & 3 \\
\text { ulcer } & \\
\text { index } & \end{array}$ & $\begin{array}{ll}\text { Day } & 6 \\
\text { ulcer } & \\
\text { index } & \end{array}$ & \begin{tabular}{l}
\multicolumn{2}{l}{ Percentage } \\
ulcer cure \\
$(\%)$
\end{tabular} \\
\hline 1 & $\begin{array}{l}\text { Distilled water } \\
(0.3 \mathrm{ml})\end{array}$ & $\begin{array}{c}3.0 \\
+ \\
0.25\end{array}$ & $\begin{array}{l}4.1 \\
+ \\
0.15\end{array}$ & $\begin{array}{l}2.9 \\
+ \\
0.27\end{array}$ & 3.34 \\
\hline 2 & $\begin{array}{l}\text { Cimetidine } \\
(100 \mathrm{mg} / \mathrm{kg})\end{array}$ & $\begin{array}{l}2.3 \\
+ \\
0.18\end{array}$ & $\begin{array}{l}* 1.0 \\
+ \\
0.04\end{array}$ & $\begin{array}{c}* 0.3 \\
+ \\
0.03\end{array}$ & 86.96 \\
\hline 3 & $\begin{array}{l}\text { Brassica oleracea } \\
\text { extract } 100 \mathrm{mg} / \mathrm{kg}\end{array}$ & $\begin{array}{l}2.9 \\
+ \\
0.21\end{array}$ & $\begin{array}{l}* 1.9 \\
+ \\
0.06\end{array}$ & $\begin{array}{l}* 0.7 \\
+ \\
0.04\end{array}$ & 75.87 \\
\hline 4. & $\begin{array}{l}\text { M. Paradisiaca extract } \\
100 \mathrm{mg} / \mathrm{kg}\end{array}$ & $\begin{array}{l}1.9 \\
+ \\
0.21\end{array}$ & $\begin{array}{l}* \quad 0.3+ \\
0.02\end{array}$ & $\begin{array}{l}* 0 \\
+ \\
0.00\end{array}$ & 100 \\
\hline 5 & $\begin{array}{l}\text { Musa paradisiacal } \\
\text { Brussica }+ \text { oleracea } \\
50 \mathrm{mg} / \mathrm{kg}+50 \mathrm{mg} / \mathrm{kg}\end{array}$ & $\begin{array}{l}2.5 \\
+ \\
0.11\end{array}$ & $\begin{array}{l}\mathrm{ns} \\
2.1 \\
+ \\
0.03\end{array}$ & $\begin{array}{l}1.9 \\
+ \\
0.00\end{array}$ & 24 \\
\hline
\end{tabular}

Keys:

$\mathrm{ns}=$ Not significant $(\mathrm{P}>0.05)$

* = Significant $(\mathrm{P}<0.05)$

Ulcer index $=10$

where $\mathrm{x}=$ total mucosal area

total mucosal lesions

(Kunchandy's method)

Percentage ulcer cure $=$

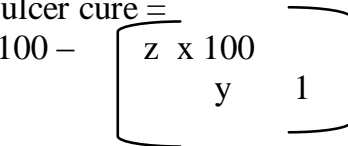

Where:

$\mathrm{Z}=$ day 6 ulcer index of the group.

$\mathrm{Y}=$ day 0 ulcer index of the group.

From the result, the co-administration of aqueous extracts of Musa paradisiaca and Brassica oleracea presented more prophylactic than curative effect. In the prophylactic test, Brussica oleracea possessed the highest percentage of ulcer protection. In the curative test, Musa paradisiaca extract possessed the highest percentage of ulcer cure.

Ulcer index

$=10$

$$
\mathrm{X}
$$

Where $\mathrm{x}=\quad$ total mucosal area

(Kunchandy's method)

$$
\text { Total mucosal lesions }
$$

Calculation-of \% ulcer inhibition

$=100-\left[\begin{array}{llll}X & & & \\ Y & & & 1\end{array}-\right]$

Where $\mathrm{X}$ = group treatment value

$\mathrm{Y}=$ control mean value.

The result shows that co-administration of the aqueous extracts of unripe fruits of Musa paradisiaca and Brussica oleracea possessed prophylactic activity against ulcer induction by indomethacin. Cimetidine, and separate administrations of Musa paradisiacal and B. Oleracea presented lesser ulcer index than the co- 
administration of both extracts. The results is in line with the investigation of anti ulcer activity of coadministration of aqueous extracts of Musa paradisiaca and Brassica oleracea

\section{FIGURES}

Figure 1: Graph of percentage ulcer inhibition against dose and agent.

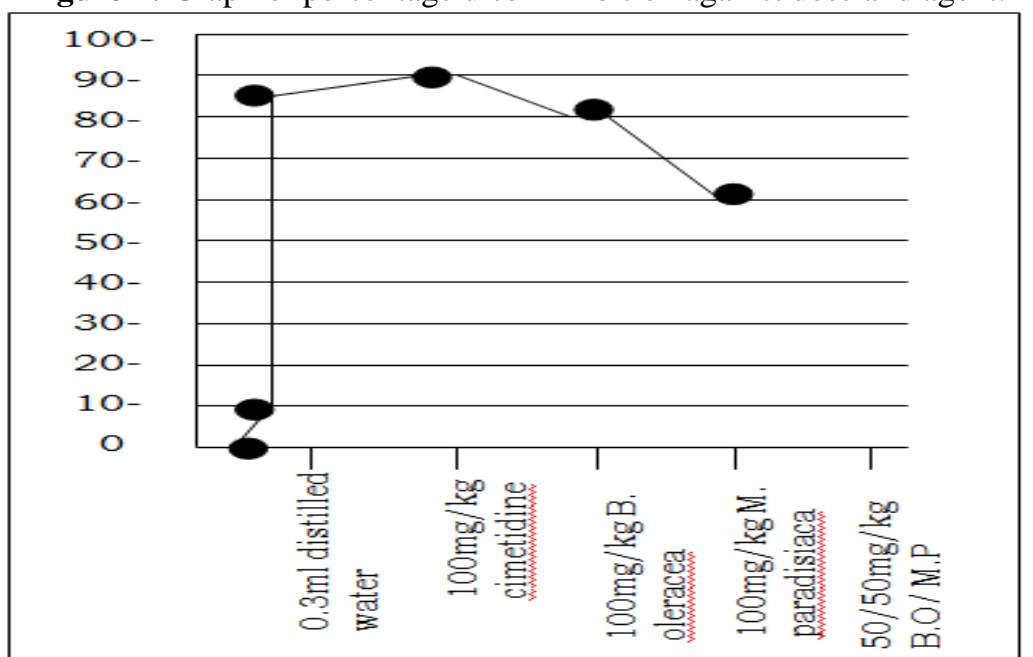

Figure2: Graph of percentage ulcer cure against Dose \& agent.

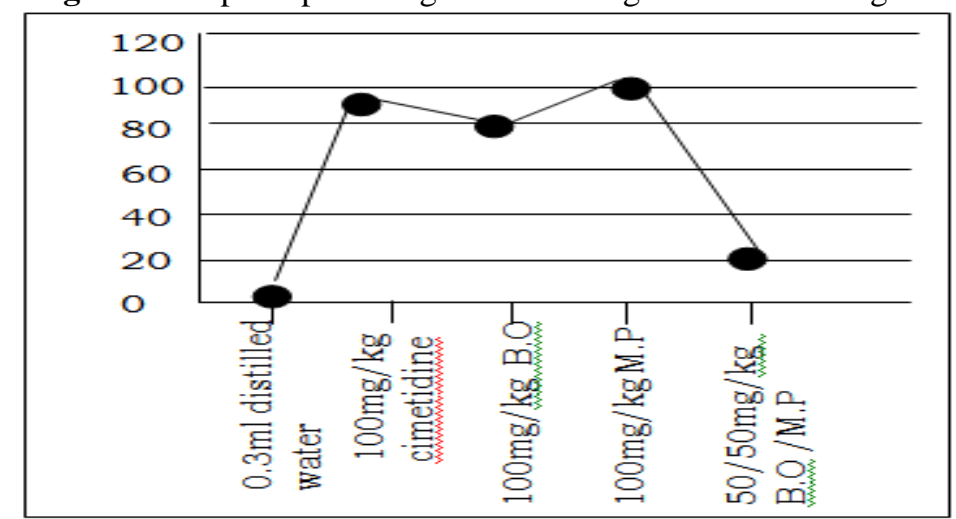

\section{Discussion}

The result showed that the co-administration of aqueous extracts of Musa paradisiacal and Brassica oleracea possessed the activity of inhibiting peptic ulcer induced by indomethacin, a potent non steroidal anti inflammatory drug ${ }^{(18)}$ The value of ulcer inhibition obtained was $59.32 \%$. The result also showed that the coadministration of both extracts possessed more prophylactic than curative effect. The value obtained from the prophylactic result test was $59.32 \%$ while that of the curative test was $24 \%$. This effect was found in albino rats.

The curative test showed that there was an ulcer index number reduction with respect to the extension of period of co-administration of Musa paradisiacal and Brassica oleracea extracts. The result also showed that cimetidine and separate administration of Musa paradisiaca and Brassica oleracea extract possessed higher prophylactic and curative activity than the co-administration of Musa paradisiaca and Brassica oleracea ${ }^{(18)}$

Peptic ulcer treatment has undergone many strides over the past few years and a number of drugs are now available for its treatment. All these drugs have brought about remarkable changes in ulcer therapy but their efficacy is still debatable due to high rate of reoccurrence. As a result, the search for the ideal anti ulcer drug continues and has also been extended to herbal drugs in search of new molecules which can afford better protection and reduce the incidence of relapse.

\section{Conclusion And Recommendation}

The result of the above study confirms the efficacy of the aqueous extracts of unripe plantain and cabbage for both the prevention and treatment of peptic ulcer, and its role in folkloric medicine as an anti ulcerogenic agent appears justified. 
Clinicians and pharmacolo-gists will find this study relevant with a view to actually formulating some conventional drugs from the extracts for use in the treatment of peptic ulcer in man.

\section{References}

[1]. Ogazi P.O. Pilot scale dehydration of plantain pulp for flour production using cabinet dryer. Nigerian food journal 1996; 8:74-79

[2]. Levis D.A, Field W.N Shaw G.P. A natural flavonoid present in unripe plantain banana pulp (Musa sapientum L. variety paradisiaca) 1999

[3]. Farnsworth A. Bingel D.R. Soejarto A.S, Guo D.D Medicinal plants in Therapy. Bull WHO 1995; 63: $965-981$.

[4]. Zohara Y, Ureil Y, Handbook of Medicinal Plants 1994; page 343.

[5]. Amos S.O Akah P.A, Bind L. Awerem N.M. Hypotensive activity of the ethanol extract of Pavettacrassipes leaves. Biol. Pharm. Bulletin 2003; 26(2); 1674-1680

[6]. Best R. Levis D.A Nasser N. The anti ulcer properties of unripe plantaim banana. British Journal of pharmcol. 1984; 82: 107-116.

[7]. Osifo B.O, Akinyika O Akinbami O, Lukambi F.A. A clinical trial on soya plantain food. University College Hospital Ibadan Nigeria 1989

[8]. Ghosal S. Bhatta Charya S.K. Concerning the anti-ulcer action of sitoindoides. Phytother. Res. 1987; 1:95-97.

[9]. Rosemary G. Family herbal guides to living life with energy, health and vitality 2001; 6(1):19.

[10]. Richo. C. Making plant medicine 2000; 2(1): 62-70

[11]. Simon Y.M. The dictionary of modern herbalism 1998; 6(1): 22-24

[12]. David H. The new holistic herbal plant of medicinal use 1995; 6(1); 19-27

[13]. Nicholas C. Medicinal uses of cabbage 1653; 5(2):18-20

[14]. Whitty H. Medicinal uses of herbs $1859 ; 8(1): 14-17$

[15]. Lanagason R.B, Akunyili D.N. Akubue P.I A preliminary study of the gastrointestinal tract actions of some Nigerian Medicinal plants. Journal of Nigerian Medicinal plants 1994; 65: 235-240.

[16]. Cheney G. The anti ulcer properties of cabbage. British Journal of pharmacology 1949; 67:98-102

[17]. Lorke D. A new approach to practical acute toxicity testing. Archives of Toxicology 1983

[18]. Beil W. Birkholz W. Sewing K.F. Effects of favonoids on parietal cell acid secretion, gastric mucosal, prostaglandin production and helicobactor pylori growth. Arzneimitelforschung 1995; 45697-700. 